\title{
Albanian State Policy to National Minorities on Educational and Cultural Viewpoint After 1990
}

\author{
Jani Sota Ph.D. \\ "Aleksandër Moisiu", University Durrës \\ E-mail:janisota@yahoo.com
}

Doi: 10.5901/mjss.2013.v4n4p91

\section{Abstract}

Through this topic will be discussed the practical implementation of educational and cultural process of Albanian State towards national minorities after 1990's. We will try to give answer on how practically are implemented such policies within the legal, cultural and social framework of national minorities in Albania. Study methodology is based on real achievements of the democratic state, especially in educational context. In the educational framework of national minorities in Albania after 90's there have been real and concrete achievements. Firstly, these achievements are seen in the educational structure of national minorities, plans, educational programs and school specific texts. Also, there will be taken in consideration the recognition from international organizations and the continuous trials done and being done for the recognition of local and international legislation, convents and specific recommendations, principles and guidelines previewed on "European Charter on Regional and Minority Language", "Framework Convent for the Protection of National Minorities" etc.

Key words: National minority, education, culture, legislation, Albania.

\section{Brief historical overview of national minorities living in Albania}

Historical tradition in Albania has moved on the road to recognition as a national minority of those minorities who have a parent nation, which have common characteristics, such as: spiritual constitution, language, culture, customs and traditions, religion etc. As such, minorities by nationalities in Albania are considered Greek, Macedonian and Montenegrin minorities. Roma and Aromanians are recognized and respected as linguistic minority.

Greek National Minorities, live in South Albania, bordering on Greece which comprises the largest national minority in number. According to data from the census of Population and Housing 1989, the number of this population is 58,758 people or $1.8 \%$ of the population, ${ }^{1}$ distributed geographically as follows:

Table. $1^{2}$

\begin{tabular}{|l|l|r|r|}
\hline $\mathbf{N r}$ & Districts & Greek Minority & General Population \\
\hline 1 & Saranda and Delvina & 36531 & 87768 \\
\hline 2 & Gjirokastra & 19921 & 66373 \\
\hline 5 & Berati and Kuçova & 49 & 179398 \\
\hline 4 & Fieri and Mallkastra & 123 & 245062 \\
\hline 5 & Gramshi & 13 & 43565 \\
\hline 6 & Kolonja & 20 & 24781 \\
\hline 7 & Korça and Devolli & 158 & 215221 \\
\hline 8 & Lushnja & 51 & 134280 \\
\hline
\end{tabular}

1 Statistical Yearbook of P.R. of Albania, Ministry of Economy, Department of Statistics, Tirana, 1991, p. 370.

2 General Census of Population and Housing 1989, Central Department of Statistics, Tirana, 1991, p. 359-373. 


\begin{tabular}{|c|c|c|c|}
\hline 9 & Përmeti & 442 & 39775 \\
\hline 10 & Pogradeci & 19 & 71446 \\
\hline 11 & Skrapari & 16 & 46503 \\
\hline 12 & tepelena & 57 & 49850 \\
\hline 13 & Vlora & 202 & 176788 \\
\hline 14 & Dibra & 17 & 149650 \\
\hline 15 & Elbasani and Peqini & 131 & 241950 \\
\hline 16 & Durrësi and Kavaja & 192 & 245499 \\
\hline 17 & Kruja dhe Laçi & 17 & 106852 \\
\hline 18 & Kukësi and Hasi & 17 & 101302 \\
\hline 19 & Lezha & 15 & 62001 \\
\hline 20 & Librazhdi & 33 & 71982 \\
\hline 21 & Mati & 22 & 76674 \\
\hline 22 & Mirdita & 16 & 50447 \\
\hline 23 & Puka & 17 & 48968 \\
\hline 24 & Shkodra and Malësia e Madhe & 53 & 236289 \\
\hline 25 & Tirana & 610 & 368213 \\
\hline 26 & Tropoja & 16 & 44779 \\
\hline \multicolumn{2}{|c|}{ Albanian Total } & 58758 & 3185416 \\
\hline
\end{tabular}

By analyzing the above table, the majority of the Albanian national minority live in southern districts of Saranda, Delvina and Gjirokastra. Saranda district consists of 64 villages of which 35 are inhabited mainly by members of the Greek minority and the rest is populated by Albanians. Almost all the villages, especially those inhabited by the Greek minority, 50\%-70\% of the population are thought to have immigrated to Greece. (Austin and Perry 1994)

Following observation made by Albanian Helsinki Committee, it turns out that "by the year in 1990, in Saranda, there were about 17.000 inhabitants, of whom 7.500 were members of the Greek national minority". ${ }^{3}$ Currently the city has 30,000 inhabitants. New residents of the last years "are mainly from the villages of the districts of Vlora and Gjirokastra". It should be noted that the reasons for coming are purely economic. As a coastal city, Saranda offers numerous employment opportunities, especially in the fields of tourism and trade. According to this survey, "in the city, members of the Greek national minority are not more than 3.500 people, the rest, for economic reasons, have immigrated to Greece". (Istvan 1991)

Delvina district counts 47 villages, of which 18 villages are populated almost entirely from the Greek minority and 4 villages are mixed, Albanian and Greek. (Austin 1993). In this district, "the Greek national minority population is 15.000 inhabitants and mainly concentrated in the city of Delvina". ${ }^{4}$ Recent years, more than half of the Albanian population has migrated to Greece and about 2/3 of the Greek minority population. Only in the city of Delvina, compared to 1990 census, the population was halved from 8,000 to 4,000 inhabitants, while the population of the Greek minority of the city from 2000 residents in 1990, currently has 500 residents. Although majority of people have moved, they are in contact with their family.

In the district of Gjirokastra is the next big band center of Greek national minority in Albania, divided into Lower Dropulli area and in the area of Upper Dropulli. The whole area lies among Gjirokastra district to the border with Greece. Almost all the villages of the area are entirely inhabited by the Greek minority. Lower Dropulli has a total of 16 villages

${ }^{3}$ Human Rights in People Socialist Republic of Albania, Minnesota, Advocates for Human Rights, Minneapolis, January 1990, p. 8-9.

4 Minorities and the protection of their rights in Albania (conventions, legislation, reports and explanatory material on minorities) Albanian Centre for Human Rights, Tirana, 2005, p. 152. 
with about 8,100 residents, and some of them are: Derviçani, Vanistera, Sofratika, Terihati, Grapshi, Glina etc. While Upper Dropulli has had 8,400 inhabitants, of whom may be mentioned Jergucati, Bularati, Sotira, Vriseraja, Kakavija, Koshovica, Argjionikolla, etc. Also, it should be mentioned that 2 other villages inhabited by members of the Greek national minority are located in the Permet district.

In April 2001, the state statistical unit of the Republic of Albania and the Department of National Minorities at the Ministry of Foreign Affairs published a present figure, which they called "assessment" on the basis of present population.... According to this evaluation, were present in Republic of Albania, 35,829 people of Greek origin, accounting for $1.1 \%$ of the total population. (Berxholli 2005)

Macedonian national minority, are concentrated mainly in the area of Prespa, in the southeastern corner of Albania, on the border with the former Yugoslav Republic of Macedonia and Greece by an area $213.9 \mathrm{~km}^{2},{ }^{5}$ and in the province of Golloborda. Regarding number potential of the Macedonian community, INSTAT provides a contingent of 4.148 inhabitants, which means 236 inhabitants per $\mathrm{km}^{2}$ (INSTAT 2006). From the administrative point of view, the nine villages of the Prespa area are: Lajthiza, Pusteci, Zaroshke Cerje, Shulini, Gollomboqi, Bezmishti, Gorica Great and Small Gorica, stretching along the lake Prespa and form a municipality named Commune of Prespa with the village center Pustec. On economic activity, the local residents are engaged mainly in agriculture, livestock, fishing and trade.

After 1990, the community had the same demographic specifics as well as the rest of the population of the Republic of Albania. Especially province Gollobord has had a lot of internal migration mainly located in Tirana, Elbasan, Korca.

Montenegrin national minority, focused on northwest Albania, mainly in some small villages such as: Gril, Omaraj and Borici Small Vraka area, near Shkodra Lake and near the border with Montenegro. According to statistics of 1989 , this retail consists of approximately 1510 people ${ }^{6}$ which has been able to maintain its compactness as a national minority, language, culture, religion, traditions of the country of origin, etc.

With the beginning of the democratic process, after 1990, the Montenegrin national minority left almost entirely to Montenegro. Economic difficulties and the tensions created in the former Yugoslavia pushed a piece of evacuees to return to their homes in Albania. Today we can say that, from 2,000 residents moved, 600 of them have returned to their homes ${ }^{7}$. Others continue to live in Montenegro or have been moved to other countries in Western Europe, the U.S. or Canada. However, it should be noted that in most cases, they maintain regular contact with their families and relatives, and continue to preserve and maintain their homes and properties in Albania.

Roma. Arrival of Roma in Albania is thought to date back over XV century with the Ottoman occupation. Roma settlements are more in the middle of southern Albania, due to the mild climate of these regions. They consist of four main tribes: Kallbuxhinj (Tirana, Elbasan, Pogradec, Korce, Bilisht, Gjirokastër, Saranda; Meçkar (Lushnje, Fier, Vlora); Kurtof - distributed; Cergars - nomads. ${ }^{8}$

It should be noted that, until the '50s Roma had a nomadic live. According to Prof. Arqile Bërxoli, "Only in the 1955 census there were $930 \mathrm{Gabel}$, of whom 264 men and 266 women" (Berxholli 2005).

By regime changes, many Roma families have come from other cities and districts of Albania and are concentrated in the outskirts of Tirana, which provides them with greater opportunities, particularly for trade. While another part of the Roma have begun again in nomad life. Also, many families for several months a year emigrate to Greece or the Former Yugoslav Republic of Macedonia.

In Albania, according to International Minority Rights Group "Roma have kept their traditional language spoken in their environments, but write in rare cases, as in Albania there were no Roma schools". ${ }^{9}$ According to them, "in 1995, the number of Roma was about 100 thousand people". (Berxholli 2000) And in 2001, it turns out that the in Republic of Albania live 109.000 Roma (Berxholli 2003).

Aromanians. Among minority in Albania live Aromanians, mostly known as Vlachs. In terms of time, the population of Aromanians is estimated as an early historical population, perhaps around the $\mathrm{VI}$ century and later population, perhaps the beginning of the XX century. During the two phases of the populating time, Aromanians emerged as nomadic, which step by step, with a gradual stabilization active in other economic activities, agriculture and more crafts in the cities.

Ancient Aromanian population settled in the rural areas of Myzeqe, Fier and Vlora, Frasher in Permet, Mokërr in Pogradec, in Kolonja, etc., and in some cities like in Korçë, Tirana, Berat, Elbasan and Durres. Population of the country

\footnotetext{
${ }^{5}$ Protection of minority rights ..., Cited edition, p. 154.

${ }^{6}$ Shekulli Newspaper, February 25, 2004, p. 17.

${ }^{7}$ Report on National Minorities in Albania - 2001, p. 4

${ }^{8}$ Research on Minorities' Policies and Funding strategies in Albania, Albanian Helsinki Committee - 2007, p. 23.

${ }^{9}$ Research on Minorities' Policies ... Publication cited, p. 63
} 
with late Aromanian is made by people coming from plateau of Mount Pindos in Greece. This branch is known in Albania named "kucovllahë" or "Sarakatsans" (Kycyku 1998). It should be noted that this population retained until the '50s, its nomad livestock character and its stabilization associated with the so-called "end of socialist cooperation of agriculture "10 during the communist dictatorship in Albania.

After this time, the movement of Aromanian population in Albania and all its demographic evolution underwent changes according to demographic and socio-economic laws, as well as the entire population of the country in which it was fully integrated. For the first time data on the number of Aromanians in Albania are in the 1950 Minority census. This census counted 2.381 residents of the Vlach population and in the 1955 census, the number of Vlach population results in 4.249. But in late registrations there are no data on the number of Aromanians in Albania.

After 1990, the Aromanians organized into associations "Armeni-Alban", "Vlach Association Voskopoja" and "Aefallofisi". These associations play an important role in the preservation of language, culture and traditions. Also, they have their newspaper "Fratia Brotherhood," which comes out once a month, in Albanian and Aromanian.

It is important to stress that, national minorities in Albania are identified in numerical terms only in cases of general census population of the whole country.

Table. 2

\begin{tabular}{|c|c|c|}
\hline Year & $\begin{array}{l}\text { Number of population } \\
\text { National Minority }\end{array}$ & $\begin{array}{l}\text { Minority percentage of the } \\
\text { country's total population }\end{array}$ \\
\hline 1960 & 44570 & 2,7 \\
\hline 1979 & 54687 & 2,1 \\
\hline 1989 & 6481 & 2,0 \\
\hline
\end{tabular}

Latest official information about the numerical size of the population of national minorities in Albania General census of Population and Housing 1989, published by the Department of Statistics (since 1993, appointed the Institute of Statistics (INSTAT), a body under the Council Ministers), where national minorities, according to the district of residence were recorded as follows:

Table. 3

\begin{tabular}{|l|c|c|c|c|c|}
\hline Total & Gjirokastër & Sarandë & Korçë & Tiranë & Other Districts \\
\hline 64816 & 20395 & 36773 & 4706 & 852 & 2090 \\
\hline
\end{tabular}

Notice that in the above table is not on the number of Roma and Aromanian population, the registration of which, in 1989 had no specific section.

We note that on April 1st, 2001, Albania began the Census of Population and Housing. Registration took place on the basis of the Albanian Constitution and Law no. 8669, dated 26.10.2000, in which legislative acts are designed with the assistance and under the direct monitoring of the respective international institutions. Also, it was developed based on such elements, corresponding to international conventions that Albania has signed and ratified and recommendations of the UN European Economic Commission and Eurostat for countries to implement the population and housing census for 2000 and requirements and standards of advanced and liberal European. The process of preparing the technical organizational structures, was made with financial assistance to several countries such as: Italy, Switzerland, Greece and the Council of Europe and under the direct monitoring of experts coming from European Union member countries.

In this recording its very nature did not include the declaration of nationality and religion. The registration process ran smoothly. Minority participation in the census is positive. Now they are present in the program and it creates conditions in the near future, the possibility of completing this registration with other data, such as nationality.

\section{State Policy towards the National Minority in Albanian Education}

10 Protection of minority rights ..., Cited edition, p. 156. 
Although ethnically and linguistically Albania is a homogeneous political country, the Albanian government has been faced with the problem of minorities since its establishment until today. In this context it has encountered in the Greek national minority problems, especially in the field of education.

Albania's commitments in terms of promoting the necessary conditions for national minorities to maintain and develop their culture and to preserve the essential elements of their identity as religion, language, traditions and cultural heritage of their origins after World War First World War are set with its admission to the League of Nations in December 1920. On October $2^{\text {nd }}, 1921$ Albania made a special statement before the Council of the League, through which undertook to respect the rights of national minorities within its territory in accordance with the provisions of the peace treaties after World War I.

Even after World War II, the communist regime, in view of its ideological and political goals was to be presented as an exemplary defender of national minorities, had a specific policy for Greeks and Macedonians.

With the change of regime and establishment of a pluralist system in 1991, it would lead to a collapse in the field of minority rights on the area of education. This commitment started since April 1991 according to Constitutional Provisions, Article 41, which declares "RP recognizes and guarantees the fundamental rights and freedoms of individuals and ethnic minorities consecrated in international texts". In this context, in the districts of Gjirokastër, Delvina and Saranda, where the number of this minority is significant, the network of schools has always been expanding.

Albanian state policies to this minority have been and continue to be cautious, aiming at establishing cultural, educational, scientific and developing bilingual minority children. Thus, the treatment of minorities in Albania, took a new dimension, which is clearly expressed in Albania's membership in international organizations such as the OSCE; Council of Europe, etc., ratification of almost all international conventions human rights and, in particular, to ratify without reservation the Framework Convention for the Protection of National Minorities.

Enshrined in the Constitution of the Republic of Albania in 1998 (Article 20), it would emphasize again that minorities enjoy equal rights and freedoms by law; that they have the right to express themselves, the right to maintain their ethnic, cultural, linguistic and religious roots, as well as "the right to be educated and learn in their mother tongue "(Article 14). ${ }^{11}$ Referring to this problem, we can say that the Albanian state has prudently followed international legislation related to minority education rights.

The right to use their mother tongue in private and in public is guaranteed in practice. Individuals from national minorities freely use their language in everyday life, with each other, in public meeting, in their associations, freely in campaigns, in their press, in their publications with cultural, literary, historical or science articles, the media and religious ceremonies. An important factor for the preservation and development of minority native language are also numerous public schools that work for the education of children of minority members.

In 1991, the Albanian government extended the classes in Greek language in the area where the Greek minority is concentrated not only Greek-language schools from the first grade up to four but also from fifth to eighth grade. Therefore, such schools were opened in 7 towns and villages outside this area, particularly in Saranda, Delvina and in 1992 in Gjirokastër ${ }^{12}$. Minority education was included in the Law on Human Rights and Fundamental Freedoms, which was adopted by the Albanian Parliament in April 1993. Article 26 on the rights of minority says that "all individuals belonging to a minority can be taught in their mother tongue". ${ }^{13}$

It should be noted that, before starting the school year 1993-1994, the Albanian government issued a new regulation under which pre-schools in minority area were preserved but grades fifth to eighth should have been in Albanian and in Greek ${ }^{14}$. Greek language classes begun in 7 towns and villages outside the minority area continued but never opened pre-school classes. ${ }^{15}$

Law "On the rights and fundamental freedoms", adopted by the National Assembly on March 31st,1993 Article 26 stated that: "Persons belonging to minorities have the right to learn and be taught in their mother tongue." But two days before the start of the school year 1993-1994, came Decision no. 19, issued by the Ministry of Education to close seven schools and programs changing from the fifth to the eighth grade, giving priority to Albanian language. To implement this

\footnotetext{
${ }^{11}$ The Constitution of the Republic of Albania Promulgated by Decree no. 2561, dated 22.2.2000 of the President of the Republic of Albania, Rexhep Meidani, p. 7. Article 14.

12 Human Rights in Post-Communist Albania, Human Rights Watch / Helsinki, New York, 10 may 1996. p. 114.

${ }_{13}$ First Report, Presented by the Republic of Albania, based on article 26, paragraph 1, the Council of Europe Framework Convention for the Protection of National Minorities, Tirana 2001, p. 10.

${ }_{14}$ Human Rights ..., Cited edition, p. 115.

${ }^{15}$ According to the new regulation (Government Decision no. 19), new classes in Greek can be opened only with the approval of the Ministry of Education based on the proposal of the District. In 1993, it was allowed to open new classes.
} 
they used force against students, parents and teachers. ${ }^{16}$ According to the Ministry of Education, "Gjirokastra students were offered free transportation to the village Derviçan $7 \mathrm{~km}$ further where there was the Greek school but most of them refused". 17

Omonia Association tried to open a school of its in the Greek language but that was considered illegal by the Albanian government and was closed. Albanian Ministry of Education claimed that the majority of parents and children voluntarily withdrew when it was learned that their school would not be recognized. However this is where the Greek minority representatives have objected at the time.

Under current rules, outside the minority area it can open a class in Greek language only if there are at least 32 minority students and a population where minorities are few $30 \%$ of the local population. ${ }^{18}$ Since Gjirokastra and Delvina fall into this minimum, Greek language classes here remained closed. The town of Saranda has a Greek population sufficient to authorize the opening of a school in the Greek language but here is not yet open.

Having regard to the principles and standards set out in the European Charter on Regional and Minority Languages, adopted by the Council of Europe in Strasbourg on November $5^{\text {th }}, 1992$ as well as other international documents in this field, with the proposal of the Ministry of Education, the Council of Ministers Decision no. 396, dated 22.8.1994 (As amended by the Council of Ministers no. 502, dated 05.08.1996) was an attempt to respond to the concerns of the Greek minority with regard to education (Zisi 2002). Rules provide two options for minority students who live outside the minority. First, when there are more students per class, approximately 25 , they can either be transported by bus for free in a minority school in a neighboring village, or can do 2-3 hours per week in their native language in one of major cities in the region. The new regulation also established a clear procedure to request the opening of such a school outside the areas of the minority.

A constant complaint of the Greek minority has been the lack of legislation to allow the establishment of private schools. After three years of debate, Parliament finally approved, on June 21st, 1995 a law on private education that allowed private high schools in foreign languages and religious high schools. In both cases, they were forced extra lessons in Albanian. Textbooks can come from private sources but must be approved by the Ministry of Education. For opening such a school was required a yearly announcement.

Another DCM, no. 493, dated 18.09.1995 would enable the introduction of the Greek language in general secondary schools in some districts of the south: in Gjirokastër (Derviçan and Bularat), Saranda (Livadhja) and Delvina (Aliko). ${ }^{19}$ All the laws and regulations are referred to adhere to the principles and standards set out in international acts. ${ }^{20}$

Network university system schools in the districts of Gjirokastër, Delvin, Saranda is fully formed and provides all the educational needs of the Greek national minority. Although ten years before the demographic transition were very irregular and resulted in the drastic decline in the number of students in these areas, a network of well-maintained schools teaching all three levels. The balance of learning both languages is more in favor to the mother tongue.

Pre University cycle subjects became all in Greek language and in an amount of 30 hours reading and language are developed. In percentage, this ratio is $90 \%$ to $10 \%$, while the high-school is $60 \%$ to $40 \%$. To ensure this minority education in these districts there are school on a minimum number of students, outside any formal norm. ${ }^{21}$

Tab. 4. Statement of the number of minority students for the academic year $2001-2002$

\begin{tabular}{|l|c|c|c|}
\hline District & Pre and University cycles & High School Education & Personel \\
\hline Gjirokastër & 546 & 202 & 136 \\
\hline Sarandë & 75 & 275 & 51 \\
\hline Delvinë & 43 & & 11 \\
\hline
\end{tabular}

\footnotetext{
${ }^{16}$ Interview with Kristaq Toli, Gjirokatër, July 5, 1994.

${ }_{17}$ Report of the Ministry of Education of the Republic of Albania, Tirana, 1993, p. 12.

${ }_{18}$ Regulation on Education of the Greek minority in Albania, Tirana, August 1994, p. 18-19.

$19 \mathrm{lbid}$, p. 133

${ }^{20}$ European Charter on Regional and Minority Language Framework Convention for the Protection of National Minorities.

21 Statistical Office of the Ministry of Education and Science.
} 
Another problem has also been concern about the fate of children from mixed marriages. Those who are formally registered with the Albanian national minority are not counted as part, so they can not go to these schools even if parents wish. According to the Ministry of Education, currently there are about 80 school principals in Gjirokastra, of whom 30 are from the Greek minority. ${ }^{22}$ In 1993, the University of Gjirokastra opened a department of the Greek language, which was originally frequented by 20 students, among them some Albanian. Gjirokastra also has a school for the training of teachers for schools in the Greek language. In 1995, there were four classes with a total of 132 students.

As been said above, international law sets no specific requirements in granting public education in a minority language. However, international and Albanian law for minority guarantees the right to develop its culture, including language. We think that the Albanian government is particularly sensitive to the Greek concerns regarding the language and education, as well as to create opportunities to develop minority culture, as this would affect much to ease the tensions in this region. In addition Albanian government has solved these problems right in touch with Greek representatives.

Also, the Roma in Albania have kept their traditional language, spoken in their environment. Roma write their language in rare cases, because in our country there have been no Roma schools.

\section{Towards Cooperation with International Organizations in the Field of Education and Culture to Persons Belonging to National Minorities}

In view of the efforts being made today in Albania, the economic and social integration of the Roma in the Albanian society and mainly to raise their level of education and culture, in Tirana, Shkodra, Korca, Elbasan, Fier, Gjirokastër other districts, in the neighborhood mainly inhabited by Roma families, have been built or started construction or renovation of the national education system schools where their children learn together with Albanian children.

A major contribution in this direction, along the Albanian state was "Soros" Foundation. Thus, only in 2000, the schools where Roma children constitute the majority of the students started to function in Tirana, Korca, Gjirokastra and later in the city of Shkodra. A special work is done in Gjirokastër where in the framework of the "Step by Step" program"* funded by the "Soros", created literacy courses for young Roma and multiethnic preschool classes for Roma and Albanian children aged 4-6 years. ${ }^{23}$ Another program pilot is being implemented by the "Soros" Foundation in collaboration with the Ministry of Education and Science in "Bajram Curri" Secondary School in Tirana.

Aromanians have preserved their traditional language too spoken in their environments. It has been preserved much better especially in compact groups, who live in villages and to some extent in older and middle age generation of those who live in cities. Whereas the younger generation in cities and speaks very little, not to say the least, which clearly shows that the Aromanians have reached a certain degree of integration with the local majority, though still retain some special features that we mentioned previously, such as: tradition, culture and language in the family. In this context, we think that this is the reason that people have recognized and respected Albanian Aromanians as a linguistic minority and not identified with other minority groups.

A significant development after 90-s has taken the cultural and artistic activity of members of national minorities. In all minorities are established and actively operating various organizations and associations, which play a major role in the recognition of the history, traditions and culture of these communities.

In Dropull, Gjirokastra Prefecture, the "Minority Creators Association" is attended by writers, poets, painters and artists of minority groups in the entire country and beyond. This association has carried out many activities, such as painting and photography exhibitions or exhibitions of folk material culture objects, etc. So, Folk Ensemble "Dropulli", which is one of most known in Albania, takes an active part not only in the cultural and artistic life of the country but with the direct support of the Ministry of Culture, Youth and Sports, City Hall, National Cultural Center and various private sponsors, has given numerous concerts abroad, the most prominent, of course, were the ones given in Greece.

The "Druzhba Prespa" of Liqenas commune in the prefecture of Korca, leads and organizes popular group activity for Macedonian minority villages. ${ }^{24}$ This association has organized the Liqenas festival and a variety of artistic tournaments in Albania and neighboring suburbs of the former Yugoslav Republic of Macedonia, with songs, tunes, dances and especially the costumes, have proved popular tradition values and its preservation.

22 Report of the Ministry of Education for the 1994-1995 school year , p. 37.

*The "Step by Step" is a methodology based on the idea of an open society where learning takes place on an individual basis in a child friendly environment.

${ }^{23}$ Human Rights in People ... . , Cited edition, p. 57.

${ }^{24}$ Research on Minorities' Policies ... , Cited edition, p. 39. 
In Vraka commune of Shkodra district, conducts its activity the Montenegrin minority cultural association "Moraça Rozafa", which has conducted a series of cultural and artistic activities, keeping alive the songs, dances, rituals of traditional outfits Montenegrin folk tradition.

Roma are organized into associations "Amaro Drom", which was established in Tirana and according to official information their activities are supported by four coordinating centers, mainly in the areas of Kruja, Lushnja, Fier and Korça. ${ }^{25}$ The important aspect is that this association also has Women's Forum and Youth Forum. The association plays a major role in the preservation of language, rich folklore and music. It has created a number of groups with instrument players, singers and talented dancers who have taken part in many national and international activities. Also, the association "Amaro Drom" has a football team, which has participated in national activities.

Similar events held by the association "Amaro Divas". It also has its own artistic group and has opened a course to teach musical instruments. Even the association for some years now publishes its monthly magazine, which bears the same name as well as the association itself. Also the "Romani Baxt" association has opened a kindergarten for Roma children.

Aromanians have their own association named "Armenia-Alban" (Aromanians of Albania), founded in 1991, "Aefallofisi" and "Association of Vlachs Voskopoje" established later. The "Armenia-Alban", has a wide activity, which aims to keep alive the language, culture and traditions. To achieve its goals it has organized a series of activities in which we can mention: Aromanian Song Festival held for the first time in 1996; the participation of its folklore group in the annual Festival of Balkan Aromanians in Constanca, Romania in 1997 and 1999 and have organized memorial conferences for historical events, such as May $23^{\text {rd }}$, etc. ${ }^{26}$

Initiating by the general climate of coexistence between Albanians and national minorities and political directions for a multicultural integration, to Albanian state structures practices aiming at assimilation of national minority are foreign. The care of the Albanian state is within its economical possibilities regarding the cultural and linguistic identity development of national minorities.

The state, along with the legislation and efforts for the practical implementation of this legislation in the Albanian education system has made significant steps towards educating young generation with a sense of cultural diversity assessment, the evaluation of the contribution that national minorities have made to Albanian society. Teaching human rights is part of the compulsory curriculum in all schools, as in the case of Education, Ethics, etc., also covering the problem of interpersonal relations between members of the majority and minority members, where students are educated with the feeling of respect, friendship, cooperation and mutual assistance.

In the case of History, Geography and Literature, based on school curricula, history is widely taught, traditions and culture of those countries that make up the home nations of minorities living in Albania. It should be noted that in these texts extensive analysis of comments on literary or historical works of prominent authors of the literature and culture of these countries are made.

New textbooks for Greek and Macedonian national minority schools, "literary reading language", "English language and literature readings" are prepared and published by the School Book Publishing House, in the minority language and English language are included selected parts from Greek and Macedonian minority folklore, writers and poets, as well as prominent Greek and Macedonian literature of different periods. Also, recent publications have been added for extra readings minority literature for Greek and Macedonian literature.

In the framework of the South East European Cooperation Process (SEECP) Albania together with other participating countries has committed to undertake a comprehensive study in order to eliminate the term "bad neighbors" from the texts of the history of these countries. ${ }^{27}$

An important contribution is given for the Greek Cultural Center Library, which based on the agreement between the Albanian and Greek government is open and operating in Tirana. Besides organizing various activities, such center serve to all persons interested in different fields of life in Greece and they can find a very rich literature.

Publications are also made from various non-governmental associations, such as the Union of Writers and Artists of Albania, National Museum, Art Gallery, organized from time to time various activities with a wide participation of eminent minority personalities in the areas of literature, art, culture, history, etc., to commemorate important events of minority life and their home nations, eminent personalities to promote publications and books etc.

In this context, the Ministry of Culture, Youth and Sports organized in 2003 in Tirana the National Folk Group Festival of Balkan countries, whose performances were broadcasted live by some Albanian private television channels. Also, in

25 lbid, p. 41-42.

${ }^{26}$ lbid, p. 43.

${ }^{27}$ Report of the Ministry of Education ... . . Cited edition, p. 41. 
cooperation with the agency "Karabashi", on June 2000 was organized in Tirana the National Minority Children's Festival, entitled "White Dove", which represented artistic groups of children of all national and linguistic minorities living in Albania. During this year with the direct support of this ministry, neighboring countries were present in concerts and plenty of pop music singers. Companies of National Theatres, as well as professional theater companies, especially Korca and Gjirokastra have staged theater piece authored by neighboring countries.

A number of projects organized in different regions of the country from the Albanian government in cooperation with various international organizations and in particular with "Soros" Foundation aimed at improving the participation and integration of Roma children in school. These projects, which include their involvement in sports and cultural activities, as Albanian children alike Roma have contributed to the promotion of respect, feelings of friendship and cooperation between them.

A satisfactory evaluation is generally the work performed by the print and electronic media in the promotion of tolerance and non-discrimination of national minorities. Often they have sensitized the public and relevant state bodies helping to solve various problems that have preoccupied minorities. Electronic media has occasionally prepared reports or news programs enhancing life, activity and educational problems of minorities. Likewise, they have broadcast documentaries on nature, history and archeology, social and economic development of neighboring countries, concerts of popular folk groups, music, etc.

But, however, in this respect there were also times when media giving current interest has not taken a balanced and impartial stance and has enhanced promotion of current nationalist passions. Sometimes it promotes negative stereotypes and prejudices against minorities, especially the Roma, which sometimes are considered as people property to small ordinary crimes. However, these approaches do not constitute a disturbing phenomenon and the general spirit of the media is to create a tolerant environment and peaceful coexistence with minorities.

\section{Conclusions}

Albania was the last country from Eastern communist block that ended communism, as well ending some special features of communism in Albania: the denial of free speech, press and the free movement of people and ideological indoctrination, which were almost incomparable to the former Central and Eastern European countries, the Albanian transition from totalitarianism to democracy, in particular, the development of education standards in advanced countries, it was more difficult than in other countries.

By studying the dynamics of educational developments in Albania after 90s many specialists in the field of education would say: the educational system in the Republic of Albania has generally worked well but what about the goal of education for minority? Who was the individual "produced"? What was the level of minority representatives' education?

Answers to the above questions are related to the meaning of "relativity" to the functioning of the educational system reform policies in Albania. It functioned as long as they were in line and on-line to application of the single party leading power philosophy, which perpetuated its power to the requirement of people preparation suitable for a uniform society. This conclusion is also valid for minorities of the early ' 90 s. Inversion of the social-political system would mean reversal in features and functioning of the education system, which would now prepare citizens with a new formation.

In this context, the importance of democratization and reform of education came to the fore of new governments in Albania. It should be returned to the individual freedoms that were denied, ending indoctrination. The time had come to assess what expands and balances knowledge, while respecting the plurality of interpretations that can be given to knowledge. No authoritarian procedures should practice this or that orientation education to minority population but assessing the ability of students by not allowing excessive competition to formalize the choice opportunities. Undressing education utilitarian concepts to provide minority students with the ability of evolution and adaptation are to be in the future.

For this purpose, Albania needed to ensure a functioning democratic system, and disempowering public sector monopoly. Decentralization processes enabled more local instances. Minority teachers are given the opportunity to participate in determining the content of the new education. Parents of minority students should be allowed to participate in the life of educational institutions, whether social or economic, and providing institutional managers with a charter to adapt to these new demands.

The problem of democratization and reform of education is shown before the Albanian society with full force and complications during and after 1990s. Reform of the education system in Albania is related to fundamental changes in form and content (curriculum, school documentation, organization of domestic life school), new developments at all levels 
of the education system (massive dropout hidden problems of vocational education of general secondary education), decentralization and management of university education and place of teachers in Albanian post-communist society.

In fact, these changes have affected several areas of science and knowledge which the most prominent are: Law studies (through changes in the legal framework) Pedagogy (changing forms and content of school education), Psychology (the creation of a worldview New Education as a whole, as a global trend), Sociology (New social aspects which minorities met in Albanian society after 90s), etc.

Reviews, treatises, and reliance on theories related directly or indirectly to history science see and review the present education system in Albania that among all other institutions of the society it has the potential to affect the formation of citizens who can live and work productively in a society with a growing complex dynamics.

\section{Bibliography}

Statistical Yearbook of P.R. of Albania, Ministry of Economy, Department of Statistics, Tirana, Albania, 1991. General Census of Population and Housing 1989, Central Department of Statistics, Tirana, Albania, 1991.

Austin. R, Engelbrek, Perry. Albania's Greek Minority, REF/RL Research Report, 18 March 1994.

Human Rights in People Socialist Republic of Albania, Minnesota, Advocates for Human Rights, Minneapolis, January 1990.

Zalatnaj, Istvan. "Minorities in Central and Eastern Europe", in: European Minurities, vol. 4, New York, 1991.

Austin, Robert. Albanian Grek relations: the confrontation continues, 4 August 1993.

Minorities and the protection of their rights in Albania (conventions, legislation, reports and explanatory material on minorities), Albanian Centre for Human Rights, Albania, 2005.

Bërxholli, Arqile. 2005. Minorities in Albania (Demographic Research, Albania.

INSTAT: Press Release Tirana, 24.02.2004.

Shekulli Newspaper, February 25, 2004.

Report on National Minorities in Albania - 2001, Tirana, Albania, 2001.

Research on Minorities' Policies and Funding strategies in Albania, Albanian Helsinki Committee, Tirana, Albania, 2007.

Bërxholli, Arqile. 2000. The general population censuses in Albania (historical overview), Albania.

Bërxholli, Argile. 2003. Geographic Atlas of Population of Albania, Tirana, Albania.

Kyçyku, Kopi. 1998. Aromanians of Albania in the Balkan context, Bucharest, Romania.

The Constitution of the Republic of Albania Promulgated by Decree no. 2561, dated 22.2.2000 of the President of the Republic of Albania, Rexhep Meidani.

Human Rights in Post-Communist Albania , Human Rights Watch / Helsinki, New York, 10 may 1996.

First Report, Presented by the Republic of Albania, based on article 26, paragraph 1, the Council of Europe Framework Convention for the Protection of National Minorities, Tirana, Albania, 2001.

Report of the Ministry of Education of the Republic of Albania Tirana, Albania, 1993.

Regulation on Education of the Greek minority in Albania, Tirana, August 1994.

Zisi, Roland. "Current problems of the Greek national minority education t": Pedagogical magazine , No. 2/2002, Tirana, 2002.

Assembly of the Republic of Albania Law. 7952, 21. 6. 1995, "University Education in the Republic of Albania" (adjourned).

European Charter on Regional and Minority Language Framework Convention for the Protection of National Minorities.

Statistical Office of the Ministry of Education and Science.

Report of the Ministry of Education for the 1994-1995 school year. 